\title{
Isolation of endothelial progenitor cells from human adipose tissue
}

\author{
Phuc Van Pham ${ }^{1,2, *}$, Ngoc Bich Vu ${ }^{1}$, Hoa Trong Nguyen ${ }^{1}$, Ngoc Kim Phan ${ }^{1,2}$ \\ ${ }^{1}$ Laboratory of Stem Cell Research and Application, University of Science, Vietnam National University, Ho Chi Minh city, Vietnam \\ ${ }^{2}$ Faculty of Biology-Biotechnology, University of Science, Vietnam National University, Ho Chi Minh city, Vietnam \\ *Corresponding author: pvphuc@hcmuns.edu.vn
}

Received: 20 April 2016 / Accepted: 21 May 2016 / Published online: 27 May 2016

CThe Author(s) 2016. This article is published with open access by BioMedPress (BMP)

\begin{abstract}
Adipose tissue is a rich source of stem cells, especially mesenchymal stem cells (MSCs). This study aimed to identify and isolate endothelial progenitor cells (EPCs) from human adipose tissue. Belly adipose tissues were collected from donors with consent. Stromal vascular fractions (SVFs) were extracted from adipose tissues by enzyme collagenase using commercial kits. SVFs were cultured in MSCCult medium for $24 \mathrm{~h}$ to obtain MSCs, then supernatant was collected and cell pellet cultured in EGM-2 medium to obtain adipose tissue EPCs (ADEPCs). ADEPCs were checked for surface marker expression of CD31 and VEGFR2, and for angiogenesis capability in vitro. The results showed that SVFs contained a pool of EPCs with strong angiogenesis potential and that adipose tissue is not only a source for MSCs but also for EPCs. Therefore, ADEPCs may a useful source of EPCs for vascular medicine.
\end{abstract}

Keywords: Endothelial progenitor cells, Adipose tissue, Stromal vascular fraction, Stem cells.

\section{INTRODUCTION}

Diseases related to ischemia have gradually increased in recent years. There have been many therapeutic efforts to treat ischemic heart diseases, including surgery (angioplasty, stents, atherectomy, etc.) to medications (beta-blockers, blood thinners, diuretics, etc.) (Imai et al., 2016; Kang et al., 2016; Lukasiewicz, 2016; von Segesser et al., 2016). Stem cell transplantation is a candidate therapy that has recently been tested to treat ischemia-related diseases, such as stroke (Kasahara et al., 2016; Vahidy et al., 2016; Wang et al., 2016), heart infarction (Henry et al., 2016; Li et al., 2016; Winters et al., 2016), and hindlimb ischemia (Kishimoto et al., 2016; Shin et al., 2016; Yoshida et al., 2016). There are two kinds of stem cells mainly used in transplantation studies; these include mesenchymal stem cells (MSCs) and endothelial progenitor cells (EPCs). MSCs are considered to be differentiated from mesoderm; they have shown to be of benefit in transplanted patients, leading to patient improvement (Lin et al., 2016; Yuan et al., 2016).
EPCs are another group of important stem cells; they exhibit strong angiogenesis potential and play a key role in vasculogenesis and angiogenesis (Chong et al., 2016). EPCs have been used effectively to treat hindlimb ischemia (Flex et al., 2016; Yu et al., 2015), stroke (Bai et al., 2015; Li et al., 2015), diabetic ulcer (Barcelos et al., 2009; Tam et al., 2015), and myocardial infarction (Mehmood et al., 2015; Sheng et al., 2015). However, the greatest limitation of EPC-based transplantation is the scarcity of EPCs; unlike other stem cells, EPCs exist in umbilical cord blood (Finney et al., 2006; Lin et al., 2011; Moon et al., 2013; Phuc et al., 2012), bone marrow (Ii, 2010) and peripheral blood (Donndorf et al., 2015), with extremely low numbers, and have slow proliferation in vitro. To overcome these limitations, our study is aimed at isolating and culturing EPCs from adipose tissue, as an alternative primary source.

Compared to adipose tissue-derived stem cells (ADSCs) that have been studied longer, adipose tissue derived EPCs (ADEPCs) have only recently been 
investigated and reported in the literature. There has been some controversy regarding EPCs from adipose tissue. Initially, studies showed that adipose tissue could be broken down into stromal vascular fractions (SVFs); in fact, SVFs were thought to be the mononuclear cells from adipose tissue. However, it was later demonstrated that SVFs actually contained stem cells which could differentiate into various lineages, including fibroblasts, adipocytes, pericytes, osteoblasts, chondrocytes and myocytes (Miyazaki et al., 2005; Zuk et al., 2001). Recently, cultured SVFs was reported to contain adipose-derived stem/progenitor cells (ASCs or ADSCs) or adipose- derived regenerative cells (ADRCs). ADSCs have been proven to be MSCs, or to exhibit the minimal criteria for MSC lineage, as suggested by Domicini et al. (Dominici et al., 2006).

To obtain EPCs for therapy, it has been reported that ADSCs can differentiate into ECs or EPCs (Miranville et al., 2004; Planat-Benard et al., 2004; Sumi et al., 2007). However, some studies have rejected this notion, and refute that ADSCs can differentiate into ECs/EPCs (Kondo et al., 2009). Several recent studies have indicated that adipose-derived regenerative cells (ADRCs) can differentiate into pericytes in vitro and in vivo (Amos et al., 2008; Traktuev et al., 2008; Zannettino et al., 2008). However, transplantation of ADSCs, as well as SVFs, have demonstrated neoangiogenesis and vasculogenesis in vivo(Guo et al., 2016; Zhong et al., 2016). Based on these reports, we hypothesized that ADSCs do not differentiate into EPCs, but that SVFs may contain an EPC population.

\section{MATERIALS AND METHODS}

\section{Adipose tissue collection}

All patients enrolled in this study were required to sign a consent form. All procedures used in the study were approved by the ethical committee of the hospital. Three adipose tissue samples were used in this study. Approximately $50-100 \mathrm{~mL}$ of lipoaspirate was collected from each patient in two $50 \mathrm{~mL}$ sterile syringes.

\section{Isolation of SVFs from adipose tissue}

SVFs from the adipose tissue (lipoaspirate) in syringes were collected using the SVF Rapid Kit (RegenMedLab, HCM, Vietnam). The extraction procedure was performed according to the manufacturer's instructions. Briefly, two syringes of aspirated fat were connected with 2 syringes of the Rapid kit. The syringes were put into an extraction machine with the following parameters: time: $30 \mathrm{~min}$, speed: 1 cycle/min. The lysed fat was then centrifuged at $1000 \mathrm{~g}$ for $5 \mathrm{~min}$ at room temperature to collect SVFs. Finally, SVFs were washed twice with phosphate buffered saline (PBS). The pellet was resuspended in PBS for determination of cell quantity and viability using an automatic cell counter (NucleoCounter; Chemometec, Denmark).

\section{Primary culture}

Three SVF samples were used to isolate EPCs by a 2step procedure. In the first step, SVF samples were cultured in MSCCult medium (RegenMed Lab, HCM, Vietnam) containing DMEM/F12 supplemented with antibiotic-antimycotic, epidermal growth factor (EGF), basic fibroblast growth factor (bFGF), with $10 \%$ FBS (Thermo-Scientific, MA). The cells were plated at $5 \times$ $10^{4}$ cells $/ \mathrm{mL}$ in T-75 flasks (SPL, Korea) and incubated at $37^{\circ} \mathrm{C}$ with $5 \% \mathrm{CO}_{2}$ to collect rapidly adherent cells. After $48 \mathrm{~h}$, the supernatant was collected. In the second step, the supernatant was centrifuged at $1000 \mathrm{~g}$ for $5 \mathrm{~min}$ to harvest the cell pellet. The pellet was resuspended in EGM-2 solution from the EGM-2 BulletKit (Lonza, Basel, Switzerland); 3 mL of EGM-2 was used per $3 \mathrm{~mL}$ of original supernatant. The suspension was then incubated at $37^{\circ} \mathrm{C}$ with $5 \% \mathrm{CO}_{2}$ to collect slowly adherent cells, which were considered to be adipose tissue derived endothelial progenitor cells (ADEPCs). After $7 \mathrm{~d}$, the cell medium was replaced with fresh medium, and continually replaced every subsequent $3 \mathrm{~d}$ until the cells reached $70-80 \%$ confluence. At that point, the cells were subcultured by TrypLe Express (Thermo-Scientific, MA).

\section{Flow cytometry}

Cell markers were analyzed following a previously published protocol. Briefly, cells were washed twice in PBS containing $1 \%$ bovine serum albumin (BSA). The cells were then stained with anti-CD31-FITC and antivascular endothelial growth factor receptor 2 (antiVEGFR2)-PE (both purchased from Santa Cruz Biotechnology, Canada) for ADEPCs, and anti-CD44PE, anti-CD73-PE, and anti-CD90-FITC (all purchased from Santa Cruz Biotechnology) for MSCs. Stained cells were analyzed by a FACSCalibur flow cytometer (BD Biosciences). Isotype controls were used in all analyses. 


\section{Capillary-like structure formation assay}

Capillary-like structure formation was done by an angiogenesis starter kit (Life Technologies, Carlsbad, CA, USA). Briefly, ADEPCs were seeded on 6-well flat-bottom plates coated with Geltrex Matrix and Medium 200. Eighteen hours after incubation, capillary-like structures were observed under an Axiovert microscope (Carl-Zeiss, Germany).

\section{Statistical analysis}

Significant differences between mean values were assessed by t-tests and analysis of variance (ANOVA). A P-value of $<0.05$ was considered statistically significant. All data were analyzed by GraphPad Prism 6 software.

\section{RESULTS}

\section{SVF extraction}

Three samples of adipose tissue were used to isolate SVFs. The results showed that adipose tissues contained $1.31 \pm 0.2710^{6}$ SVF cells with percent viability of $92.17 \pm 5.81 \%$.

\section{SVF culture and proliferation}

In the first step, SVFs were cultured in DMEM/F12 medium for $48 \mathrm{~h}$ to isolate MSCs. The culture supernatant was collected and placed in new flasks with fresh medium (containing EGM-2). After $48 \mathrm{~h}$ of culture, adherent cells appeared in the flasks. After 5 $\mathrm{d}$, these cells rapidly proliferated and formed colonies. Under the microscope, these colonies (or EPC candidates) exhibited the characteristic shape of EPCs (Fig. 1).
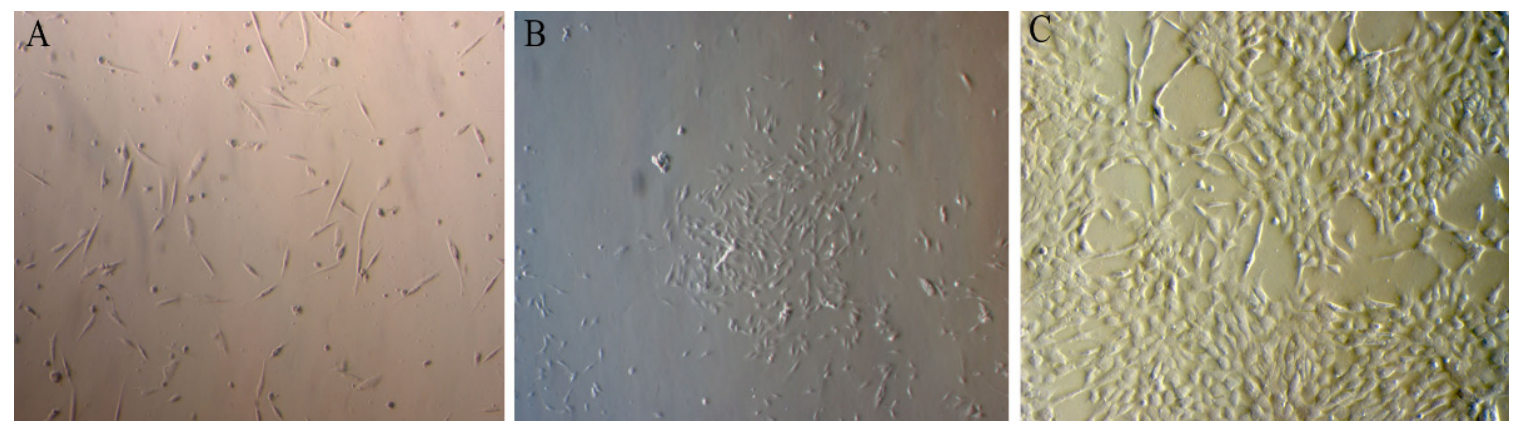

Figure 1. EPC isolation from adipose tissue. EPC candidates adhered tothe flask surface after 3 days of culture (A). Some EPC candidate colonies were formed in the culture (B). And EPCs became a homogenous population after 3 times of sub-culture. A and $\mathrm{B}$ were captured at 10x magnification, and $\mathrm{C}$ at 20x magnification.

\section{Expression of CD31 and VEGFR2}

Expression of CD31 and VEGFR2 on the surface of EPC candidates were evaluated by flow cytometry and immunocytochemistry. The results showed that the majority of AD-EPCs showed high expression of CD31 and VEGFR2, with $93.31 \pm 9.11 \%$ and $98.91 \pm 1.14 \%$ of the cells staining positive, respectively (Fig. 2F). ADEPC marker expression was also confirmed by immunocytochemistry; almost all of the ADEPCs were positive for CD31 and VEGFR2 (Fig. 2A-D). The double positive $\mathrm{CD} 31^{+} \mathrm{VEGFR} 2^{+}$population was also observed (Fig. 2E).

\section{Capillary-like network formation in vitro}

ADEPCs were assessed for in vitro capillary formation in Matrigel. As shown in Fig. 3, ADEPCs were capable of forming capillaries (Fig. 3A, D), similar to human vein endothelial cells (HUVECs) (Fig. 3B, E), while MSCs derived from the same samples of SVFs could not form capillaries (Fig. 3C, F). 

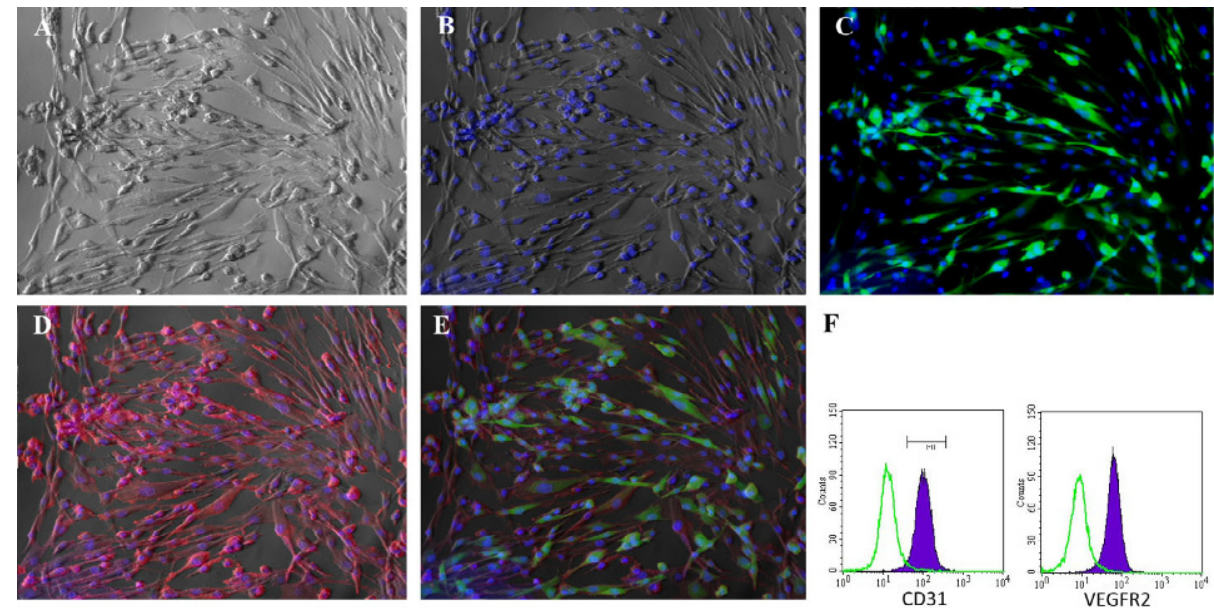

F

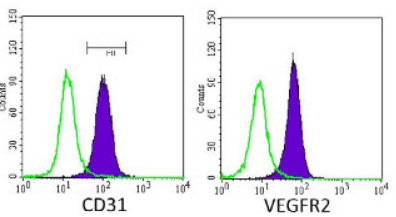

Figure 2. EPC candidates were positive with CD31 and VEGFR2. ADEPCs were stained with CD31-FITC (C), with VEGFR2-PE (D), and counterstained with DAPI for cell nuclei (B). The merged figure showed that these cells co-expressed CD31 and VEGFR2 (E). The expression of CD31 and VEGFR2 also were confirmed by flow cytometry (F). All figures were captured at 20X magnification.
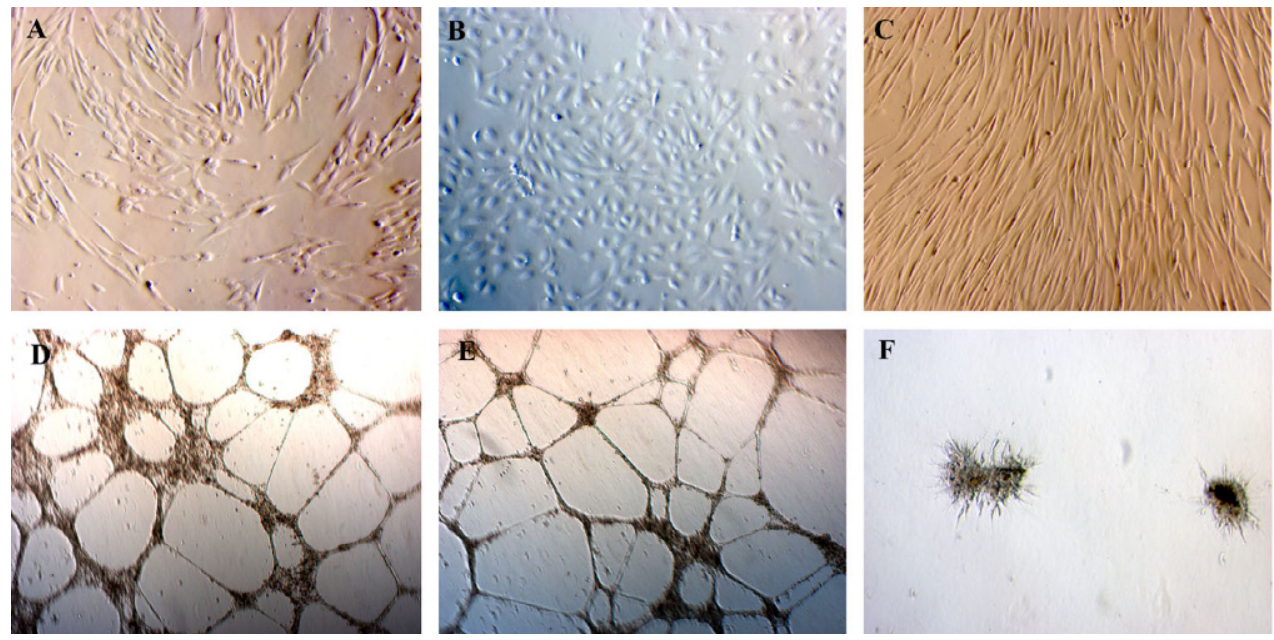

Figure 3. Capillary-like network formation in vitro of EPC candidates. ADEPCs can formed the capillary-like network when cultured in the Matrigel (D) compared to normal culture condition (A). This result was similar to HUVECs cultured in Matrigel (E) compared to adhere culture (B). However, the MSCs obtained from the same sample of adipose tissue could not form capillary-like network in Matrigel and normal condition (C and F). All figures were captured at 10X magnification.

\section{Isolation of both MSCs and EPCs from same adipose tissue samples}

We were able to isolate both MSCs (ADSCs) and ADEPCs from the same adipose tissues. In the first culture (first $24 \mathrm{~h}$ ), the adherent cells exhibited the characteristic MSC phenotypes. The cells adhered tothe flask surface with fibroblast-like shape (Fig. 4A). They also expressed particular MSC markers, such as CD44 (98.89 $\pm 3.12 \%)$, CD73 (98.78 $\pm 1.21 \%)$ and CD90
(100\%) (Fig. 4B). Although they failed to form capillary-like network formation in vitro, the cells could differentiate into osteoblasts, chondroblasts and adipocytes (Fig. 4C). In fact, after induction with an osteoblast-inducing medium, the cells stained positive with alizarin red staining. Moreover, after induction by chondrogenesis, MSCs stained positive with Safranin O staining; after induction by adipogenesis, MSCs were positive with Oil Red staining. 

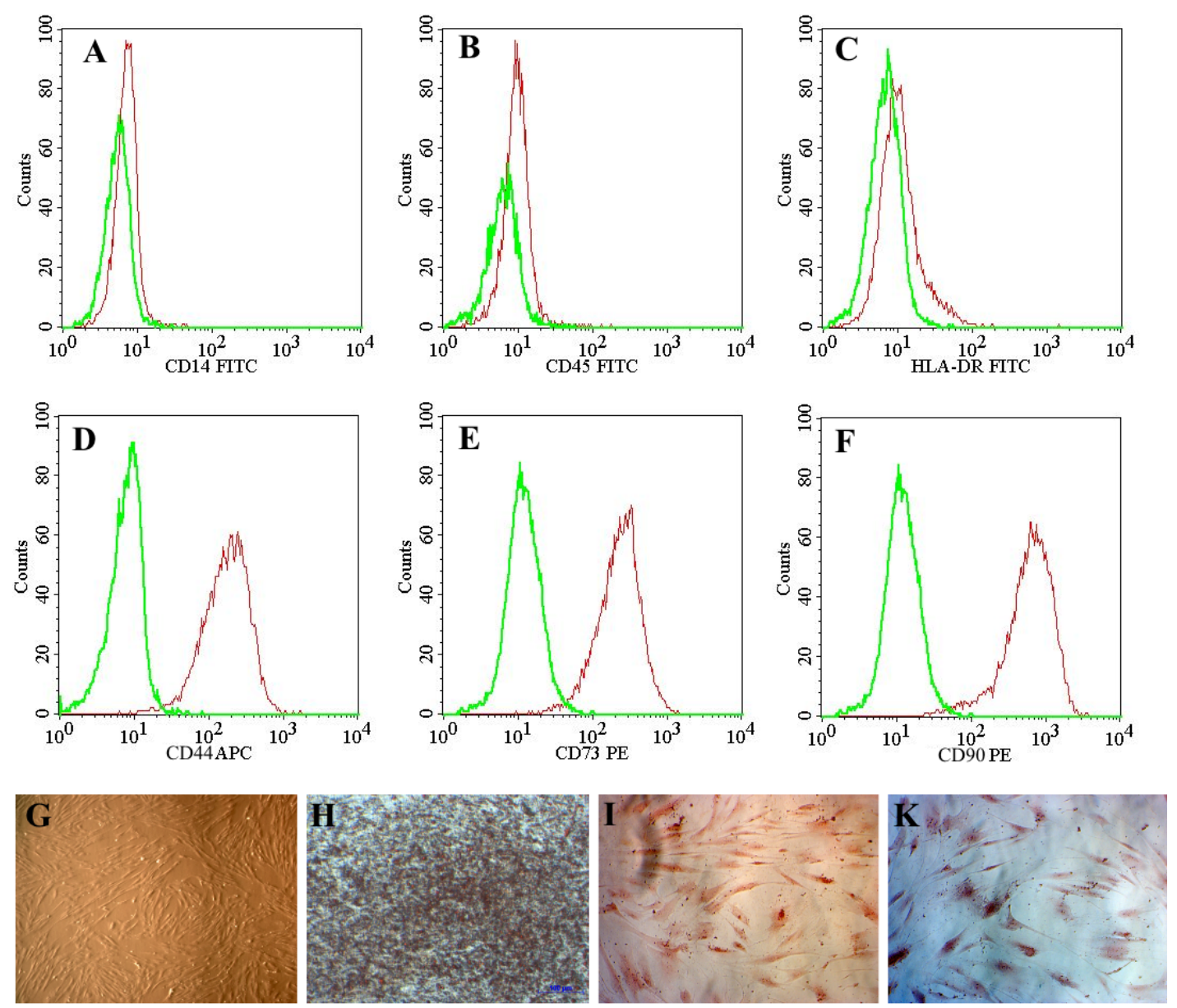

Figure 4. MSCs phenotype and characterization. MSCs from adipose tissue were positive forCD44 (D), CD73 (E) and CD90 (F), while negative with CD14 (A), CD45 (B) and HLADR (C). These cells also exhibited the fibroblast-like shape (G), successfully differentiated into adipocytes that were positive with Oil red $(\mathrm{H})$; osteoblasts that were positive with alizarin red (I), chondroblasts that were positive with Safranin $\mathrm{O}(\mathrm{K})$.

\section{DISCUSSION}

EPCs are essential stem cells in regenerative medicine as well as vascular medicine. This study evaluated adipose tissue as a potential new source for EPCs. The ADEPCs exhibited phenotypic and functional markers of EPCs. It has been noted in some previous studies that EPCs are detected, and only at low numbers, in umbilical cord blood (Finney et al., 2006; Lin et al., 2011; Moon et al., 2013; Phuc et al., 2012), bone marrow (Ii, 2010) and peripheral blood (Donndorf et al., 2015). These EPCs have been successfully applied to treat ischemia-related diseases, such as hindlimb ischemia (Flex et al., 2016; Yu et al., 2015), stroke (Bai et al., 2015; Li et al., 2015), diabetic ulcer (Barcelos et al., 2009; Tam et al., 2015), and myocardial infarction (Mehmood et al., 2015; Sheng et al., 2015).
Although the EPCs from our study were obtained from a different source (adipose tissue), they exhibited several common properties of EPCs, including expression of CD31 and VEGFR2, and capillary-like network formation in vitro(Finney et al., 2006; Ii, 2010; Lin et al., 2011; Moon et al., 2013; Phuc et al., 2012). Expression of CD31 and VEGFR2 was strong after the $3^{\text {rd }}$ cell passage. The cells demonstrated the ability to form new blood vessels in vitro, similar to HUVECs.

The isolation of EPCs derived from adipose tissue has been suggested by Planat-Benard et al. (Planat-Benard et al., 2004). Planat-Benard's procedure was not different from standard MSC isolation procedure; ADEPCs were isolated and proliferated in DMEM/F12 medium supplemented with $10 \%$ NCS. Mouse ADEPCs have been isolated and evaluated in recent years by Zhou et al (Zhou et al., 2015). Similar to 
Planat-Benard et al., Zhou et al. also used DMEM medium with $10 \%$ FBS, without any growth factors or cytokines. Both of these procedures are similar to MSC isolation that has been published in the literature (Cheng et al., 2011; Devitt et al., 2015; Francis et al., 2010).

In 2014, Navarro et al. showed that there was a cell population in SVFs exhibiting endothelial cell properties (Navarro et al., 2014). The fraction of CD14+ cells contained cells that co-expressed CD45 with some progenitor markers, such as VEGFR2 (KDR), VEGFR1 (Flt1), and Tie2 (Navarro et al., 2014). These cells also produced VEGF and bFGF at high levels, compared to MSCs (Navarro et al., 2014).

Our study can be considered as the first study to use direct cell culture procedures to isolate EPCs from adipose tissue. The principle for EPC isolation from SVFs is similar to our previously published study on isolation of EPCs from umbilical cord blood by cell culture (Phuc et al., 2012). Based on the different adherent capacities of MSCs (plastic rapidly-adherent cells) and EPCs (slowly-adherent), we successfully isolated MSCs and EPCs from the same samples of umbilical cord blood mononuclear cells. Similarly, in this study, the slowly adherent cell population from SVFs were found to be EPCs, and the rapidly adherent cells were MSCs.

\section{CONCLUSION}

Previous studies have shown that EPCs are usually isolated from umbilical cord blood, bone marrow or peripheral blood, in limited quantity. This study suggested that a new source of EPCs could be derived from adipose tissue. The ADEPCs in our study expressed endothelial cell markers, such as CD31 and VEGFR2, and formed blood vessels in vitro, similar to HUVECs. We demonstrated that EPCs can be easily isolated from adipose tissue by selecting the slowly adherent cell population from SVFs. These findings demonstrate the potential and rationale for the use of adipose tissue for EPC isolation to treat vascular diseases.

\section{Abbreviations}

ADEPCs: Adipose tissue-derived endothelial progenitor cells; EPCs: Endothelial progenitor cells; HUVEC: Human umbilical vein endothelial cells; MSCs: Mesenchymal stem cells; SVFs: Stromal vascular fraction; VEGFR2: Vascular endothelial growth factor receptor 2

\section{Acknowledgments}

This work is funded by Vietnam National University, Ho Chi Minh city, Viet Nam under grant number: TX2016-18-03.

\section{Competing interests}

The authors declare they have no competing interests.

\section{Open Access}

This article is distributed under the terms of the Creative Commons Attribution License (CC-BY 4.0) which permits any use, distribution, and reproduction in any medium, provided the original author(s) and the source are credited.

\section{References}

Amos, P.J., Shang, H., Bailey, A.M., Taylor, A., Katz, A.J., and Peirce, S.M. (2008). IFATS collection: The role of human adipose-derived stromal cells in inflammatory microvascular remodeling and evidence of a perivascular phenotype. Stem Cells 26, 2682-2690.

Bai, Y.Y., Wang, L., Peng, X.G., Wang, Y.C., Chang, D., Zheng, S., Ding, J., Li, C., and Ju, S. (2015). Non-invasive monitoring of transplanted endothelial progenitor cells in diabetic ischemic stroke models. Biomaterials 40, 43-50.

Barcelos, L.S., Duplaa, C., Krankel, N., Graiani, G., Invernici, G., Katare, R., Siragusa, M., Meloni, M., Campesi, I., Monica, M., et al. (2009). Human CD133+ progenitor cells promote the healing of diabetic ischemic ulcers by paracrine stimulation of angiogenesis and activation of Wnt signaling. Circ Res 104, 1095 1102.

Cheng, K.-H., Kuo, T.-L., Kuo, K.-K., and Hsiao, C.-C. (2011). Human adipose-derived stem cells: Isolation, characterization and current application in regeneration medicine. Genomic Medicine, Biomarkers, and Health Sciences 3, 53-62.

Chong, M.S., Ng, W.K., and Chan, J.K. (2016). Concise Review: Endothelial Progenitor Cells in Regenerative Medicine: Applications and Challenges. Stem Cells Transl Med 5, 530-538. 
Devitt, S.M., Carter, C.M., Dierov, R., Weiss, S., Gersch, R.P., and Percec, I. (2015). Successful isolation of viable adiposederived stem cells from human adipose tissue subject to long-term cryopreservation: positive implications for adult stem cell-based therapeutics in patients of advanced age. Stem Cells Int 2015, 146421.

Dominici, M., Le Blanc, K., Mueller, I., Slaper-Cortenbach, I., Marini, F., Krause, D., Deans, R., Keating, A., Prockop, D., and Horwitz, E. (2006). Minimal criteria for defining multipotent mesenchymal stromal cells. The International Society for Cellular Therapy position statement. Cytotherapy 8, 315-317.

Donndorf, P., Lube, L., Lux, C., Skorska, A., Steinhoff, G., and Kraft, K. (2015). Mobilization of Bone Marrow-Derived Endothelial Progenitor Cells following Finnish Sauna: A Pilot Study. Forsch Komplementmed 22, 246-250.

Finney, M.R., Greco, N.J., Haynesworth, S.E., Martin, J.M., Hedrick, D.P., Swan, J.Z., Winter, D.G., Kadereit, S., Joseph, M.E., Fu, P., et al. (2006). Direct comparison of umbilical cord blood versus bone marrow-derived endothelial precursor cells in mediating neovascularization in response to vascular ischemia. Biol Blood Marrow Transplant 12, 585-593.

Flex, A., Biscetti, F., Iachininoto, M.G., Nuzzolo, E.R., Orlando, N., Capodimonti, S., Angelini, F., Valentini, C.G., Bianchi, M., Larocca, L.M., et al. (2016). Human cord blood endothelial progenitors promote post-ischemic angiogenesis in immunocompetent mouse model. Thromb Res 141, 106-111.

Francis, M.P., Sachs, P.C., Elmore, L.W., and E. Holt, S. (2010). Isolating adipose-derived mesenchymal stem cells from lipoaspirate blood and saline fraction. Organogenesis 6, 11-14.

Guo, L.Z., Kim, T.H., Han, S., and Kim, S.W. (2016). AngioVasculogenic Properties of Endothelial-Induced Mesenchymal Stem Cells Derived From Human Adipose Tissue. Circ J 80, 998 1007.

Henry, T.D., Schaer, G.L., Traverse, J.H., Povisc, T.J., Davidson, C., Lee, J.S., Costa, M.A., Bass, T., Mendelsohn, F., Fortuin, F.D., et al. (2016). Autologous CD $34<$ sup $>+</$ sup $>$ Cell Therapy for Refractory Angina: 2 year Outcomes from the ACT34-CMI Study. Cell Transplant.

Ii, M. (2010). Bone marrow-derived endothelial progenitor cells: isolation and characterization for myocardial repair. Methods Mol Biol 660, 9-27.

Imai, H., Watanabe, K., Miyagishima, T., Yoshimoto, Y., Kin, T., Nakatomi, H., and Saito, N. (2016). The outcome of a surgical protocol based on ischemia overprotection in large and giant aneurysms of the anterior cerebral circulation. Neurosurg Rev.

Kang, W.Y., Campia, U., Ota, H., Didier, R.J., Negi, S.I., Kiramijyan, S., Koifman, E., Baker, N.C., Magalhaes, M.A., Lipinski, M.J., et al. (2016). Vascular access in critical limb ischemia. Cardiovasc Revasc Med 17, 190-198.

Kasahara, Y., Yamahara, K., Soma, T., Stern, D.M., Nakagomi, T., Matsuyama, T., and Taguchi, A. (2016). Transplantation of hematopoietic stem cells: intra-arterial versus intravenous administration impacts stroke outcomes in a murine model. Transl Res.

Kishimoto, S., Inoue, K.I., Nakamura, S., Hattori, H., Ishihara, M., Sakuma, M., Toyoda, S., Iwaguro, H., Taguchi, I., Inoue, T., et al. (2016). Low-molecular weight heparin protamine complex augmented the potential of adipose-derived stromal cells to ameliorate limb ischemia. Atherosclerosis 249, 132-139.

Kondo, K., Shintani, S., Shibata, R., Murakami, H., Murakami, R., Imaizumi, M., Kitagawa, Y., and Murohara, T. (2009). Implantation of adipose-derived regenerative cells enhances ischemia-induced angiogenesis. Arterioscler Thromb Vasc Biol 29, 61 66.

Li, G.H., Luo, B., Lv, Y.X., Zheng, F., Wang, L., Wei, M.X., Li, X.Y., Zhang, L., Wang, J.N., Chen, S.Y., et al. (2016). Dual effects of VEGF-B on activating cardiomyocytes and cardiac stem cells to protect the heart against short- and long-term ischemiareperfusion injury. J Transl Med 14, 116.

Li, Y.F., Ren, L.N., Guo, G., Cannella, L.A., Chernaya, V., Samuel, S., Liu, S.X., Wang, H., and Yang, X.F. (2015). Endothelial progenitor cells in ischemic stroke: an exploration from hypothesis to therapy.J Hematol Oncol 8, 33.

Lin, K.C., Yip, H.K., Shao, P.L., Wu, S.C., Chen, K.H., Chen, Y.T., Yang, C.C., Sun, C.K., Kao, G.S., Chen, S.Y., et al. (2016). Combination of adipose-derived mesenchymal stem cells (ADMSC) and ADMSC-derived exosomes for protecting kidney from acute ischemia-reperfusion injury. Int J Cardiol 216, 173-185.

Lin, R.Z., Dreyzin, A., Aamodt, K., Dudley, A.C., and MeleroMartin, J.M. (2011). Functional endothelial progenitor cells from cryopreserved umbilical cord blood. Cell Transplant 20, 515-522.

Lukasiewicz, A. (2016). Treatment of acute lower limb ischaemia. Vasa 45, 213-221.

Mehmood, A., Ali, M., Khan, S.N., and Riazuddin, S. (2015). Diazoxide preconditioning of endothelial progenitor cells improves their ability to repair the infarcted myocardium. Cell Biol Int 39, 1251-1263.

Miranville, A., Heeschen, C., Sengenes, C., Curat, C.A., Busse, R., and Bouloumie, A. (2004). Improvement of postnatal neovascularization by human adipose tissue-derived stem cells. Circulation 110, 349-355.

Miyazaki, T., Kitagawa, Y., Toriyama, K., Kobori, M., and Torii, S. (2005). Isolation of two human fibroblastic cell populations with multiple but distinct potential of mesenchymal differentiation by ceiling culture of mature fat cells from subcutaneous adipose tissue. Differentiation 73, 69-78.

Moon, S.H., Kim, S.M., Park, S.J., Kim, H., Bae, D., Choi, Y.S., and Chung, H.M. (2013). Development of a xeno-free autologous culture system for endothelial progenitor cells derived from human umbilical cord blood. PLoS One 8, e75224.

Navarro, A., Marin, S., Riol, N., Carbonell-Uberos, F., and Minana, M.D. (2014). Human adipose tissue-resident monocytes exhibit an endothelial-like phenotype and display angiogenic properties. Stem Cell Res Ther 5, 50.

Phuc, P.V., Ngoc, V.B., Lam, D.H., Tam, N.T., Viet, P.Q., and Ngoc, P.K. (2012). Isolation of three important types of stem cells from the same samples of banked umbilical cord blood. Cell and Tissue Banking 13, 341-351.

Planat-Benard, V., Silvestre, J.S., Cousin, B., Andre, M., Nibbelink, M., Tamarat, R., Clergue, M., Manneville, C., SaillanBarreau, C., Duriez, M., et al. (2004). Plasticity of human adipose 
lineage cells toward endothelial cells: physiological and therapeutic perspectives. Circulation 109, 656-663.

Sheng, Z.L., Yao, Y.Y., Li, Y.F., Fu, C., and Ma, G.S. (2015). Transplantation of bradykinin-preconditioned human endothelial progenitor cells improves cardiac function via enhanced Akt/eNOS phosphorylation and angiogenesis. Am J Transl Res 7, 1214-1226.

Shin, J.Y., Yoon, J.K., Noh, M.K., Bhang, S.H., and Kim, B.S. (2016). Enhancing Therapeutic Efficacy and Reducing Cell Dosage in Stem Cell Transplantation Therapy for Ischemic Limb Diseases by Modifying the Cell Injection Site. Tissue Eng Part A 22, 349-362.

Sumi, M., Sata, M., Toya, N., Yanaga, K., Ohki, T., and Nagai, R. (2007). Transplantation of adipose stromal cells, but not mature adipocytes, augments ischemia-induced angiogenesis. Life Sci 80, 559-565.

Tam, J.C., Ko, C.H., Lau, K.M., To, M.H., Kwok, H.F., Siu, W.S., Lau, C.P., Chan, W.Y., Leung, P.C., Fung, K.P., et al. (2015). Enumeration and functional investigation of endothelial progenitor cells in neovascularization of diabetic foot ulcer rats with a Chinese 2-herb formula. J Diabetes 7, 718-728.

Traktuev, D.O., Merfeld-Clauss, S., Li, J., Kolonin, M., Arap, W., Pasqualini, R., Johnstone, B.H., and March, K.L. (2008). A population of multipotent CD34-positive adipose stromal cells share pericyte and mesenchymal surface markers, reside in a periendothelial location, and stabilize endothelial networks. Circ Res 102, 77-85.

Vahidy, F.S., Rahbar, M.H., Zhu, H., Rowan, P.J., Bambhroliya, A.B., and Savitz, S.I. (2016). Systematic Review and MetaAnalysis of Bone Marrow-Derived Mononuclear Cells in Animal Models of Ischemic Stroke. Stroke.

von Segesser, L., Marinakis, S., Berdajs, D., Ferrari, E., Wilhelm, M., and Maisano, F. (2016). Prevention and therapy of leg ischaemia in extracorporeal life support and extracorporeal membrane oxygenation with peripheral cannulation. Swiss Med Wkly 146, w14304.

Wang, Q., Duan, F., Wang, M.X., Wang, X.D., Liu, P., and Ma, L.Z. (2016). Effect of stem cell-based therapy for ischemic stroke treatment: A meta-analysis. Clin Neurol Neurosurg 146, 1-11.

Winters, A.A., Bou-Ghannam, S., Thorp, H., Hawayek, J.A., Atkinson, D.L., Bartlett, C.E., Silva, F.J., Hsu, E.W., Moreno, A.P., Grainger, D.A., et al. (2016). Evaluation of Multiple Biological Therapies for Ischemic Cardiac Disease. Cell Transplant.

Yoshida, S., Yoshimoto, H., Hirano, A., and Akita, S. (2016). Wound Healing and Angiogenesis through Combined Use of a Vascularized Tissue Flap and Adipose-Derived Stem Cells in a Rat Hindlimb Irradiated Ischemia Model. Plast Reconstr Surg 137, 14861497.

Yu, P., Li, Q., Liu, Y., Zhang, J., Seldeen, K., and Pang, M. (2015). Pro-angiogenic efficacy of transplanting endothelial progenitor cells for treating hindlimb ischemia in hyperglycemic rabbits. J Diabetes Complications 29, 13-19.

Yuan, H., Guan, J., Zhang, J., Zhang, R., and Li, M. (2016). Exosomes secreted by human urine-derived stem cells accelerate skin wound healing by promoting angiogenesis in rat. Cell Biol Int.
Zannettino, A.C., Paton, S., Arthur, A., Khor, F., Itescu, S., Gimble, J.M., and Gronthos, S. (2008). Multipotential human adipose-derived stromal stem cells exhibit a perivascular phenotype in vitro and in vivo. J Cell Physiol 214, 413-421.

Zhong, Z., Gu, H., Peng, J., Wang, W., Johnstone, B.H., March, K.L., Farlow, M.R., and Du, Y. (2016). GDNF secreted from adipose-derived stem cells stimulates VEGF-independent angiogenesis. Oncotarget.

Zhou, L., Xia, J., Qiu, X., Wang, P., Jia, R., Chen, Y., Yang, B., and Dai, Y. (2015). In Vitro Evaluation of Endothelial Progenitor Cells from Adipose Tissue as Potential Angiogenic Cell Sources for Bladder Angiogenesis. PLoS ONE 10, e0117644.

Zuk, P.A., Zhu, M., Mizuno, H., Huang, J., Futrell, J.W., Katz, A.J., Benhaim, P., Lorenz, H.P., and Hedrick, M.H. (2001). Multilineage cells from human adipose tissue: implications for cellbased therapies. Tissue Eng 7, 211-228.

\section{Cite this article as:}

Pham, P., Vu, N., Nguyen, H., \& Phan, N. (2016). Isolation of endothelial progenitor cells from human adipose tissue. Biomedical Research and Therapy, 3(5), 645-652. 